\title{
Carbon in Trees in Tasmanian State Forest
}

\author{
M. T. Moroni, T. H. Kelley, and M. L. McLarin \\ Forestry Tasmania, 79 Melville Street, Hobart TAS 7000, Australia \\ Correspondence should be addressed to M. T. Moroni, martin.moroni@forestrytas.com.au
}

Received 16 September 2010; Revised 24 November 2010; Accepted 27 December 2010

Academic Editor: Marie-Charlotte Nilsson

Copyright ( $) 2010$ M. T. Moroni et al. This is an open access article distributed under the Creative Commons Attribution License, which permits unrestricted use, distribution, and reproduction in any medium, provided the original work is properly cited.

\begin{abstract}
The mass of carbon (C) in standing trees on $1.5 \mathrm{M}$ ha of Tasmanian State forest was $163 \mathrm{Tg}$ C, with $139 \mathrm{Tg}$ in eucalypt forest. The highest $\mathrm{C}$ densities occurred in the tallest, highest crown cover, mature, wet eucalypt forest, representing $0.2 \%$ by area containing only $1.3 \mathrm{Tg}$ C. Shorter mature forests with lower crown cover contained $21-68 \%$ of this C density. Rainforests and forests containing regrowth or silvicultural regeneration components also contained lower C densities. Landscape-level C saturation of Tasmanian State forest could only be achieved when all forest was simultaneously mature eucalypt forest. This would sequester an additional $93 \mathrm{Tg} \mathrm{C}$ into trees, but would require fire to convert existing mixed forest and rainforest to eucalypt forest, and subsequent estate wildfire prevention while eucalypt forests mature and the prevention of eucalypt forests progressing to less Cdense rainforest. Theoretical $\mathrm{C}$ saturation at the landscape level is therefore ecologically impossible.
\end{abstract}

\section{Introduction}

Storing carbon (C) in forests as a method to reduce atmospheric greenhouse gas concentrations has recently received significant attention internationally (Ter-Mikaelian et al. [1]) $[2,3]$ and in Australia [4-10]. This in turn has led to discussion on actual and potential $\mathrm{C}$ storage on forested landscapes. In Australia, there has been a focus on very C-dense forests with few studies examining carbon storage in the full range of vegetation and forest cover types and forest age classes typical of forested landscapes. A proper understanding of the role of $\mathrm{C}$ in any forest estate requires a landscape view of $\mathrm{C}$ storage and its link to forest dynamics. However, discussions of forest $\mathrm{C}$ in Australia to date either lack a landscape view or have derived a landscape view from sites representing a small and atypical proportion of the forest landscape.

Recently the concept of Carbon Carrying Capacity has received significant attention. Roxburgh et al. [6], Mackey et al. [8], and Keith et al. [10] define the concept of Carbon Carrying Capacity as "the mass of carbon able to be stored in a forest ecosystem under prevailing environmental conditions and natural disturbance regimes, but excluding anthropogenic disturbance." However, estimates of Carbon Carrying Capacity in the above studies are demonstrated as the difference between current forest carbon stocks and those anticipated for an area when supporting solely mature, carbon-saturated forests. Such calculations estimate the theoretical biological maximum forest carbon stocks achievable or Theoretical C Saturation [11]. Such a procedure will overestimate landscape-level Carbon Carrying Capacity by failing to account for the effect of recent wildfire on forest ageclass structure and carbon storage [12]. Keith et al. [10] and Mackey et al. [8] estimate forests of south-eastern Australia are able to support live biomass with an average landscapelevel C content of $289 \mathrm{MgCha}^{-1}$ or $360 \mathrm{MgCha}^{-1}$ in the total biomass, which is high compared to IPCC values for the temperate biome [13], which Mackey et al. [8] attribute to anthropogenic disturbance across the IPCC forest dataset. Roxburgh et al. [6], Mackey et al. [8], and Keith et al. [10] highlight the gap between current and estimated potential maximum terrestrial carbon stocks, where the difference between actual and potential carbon stocks is presented as landscape carbon sequestration potential. This sequestration potential is in turn presented as the potential of forests to reduce atmospheric $\mathrm{CO}_{2}$ concentrations.

Inventory divides $1.5 \mathrm{M}$ ha of Tasmanian State forest into Forest Classes encompassing important ecological parameters such as forest type and elevation and by landuse classes which are described in greater detail below. 
TAble 1: Forest classes of Tasmanian state forest and their description.

\begin{tabular}{ll}
\hline $\begin{array}{l}\text { Forest } \\
\text { class }\end{array}$ & Forest class descriptor \\
\hline Eucalypt forest $^{\mathrm{a}}$ & \\
\hline Mature $^{\mathrm{a}}$ & \\
1 & E1a\&b without regrowth \\
2 & E1c\&d without regrowth \\
3 & E2a\&b without regrowth \\
4 & E2c\&d without regrowth \\
5 & E+3a\&b without regrowth \\
6 & E+3c\&d without regrowth \\
7 & E-3a\&b without regrowth \\
8 & E-3c\&d without regrowth \\
9 & E4a,b\&c without regrowth \\
10 & E4d without regrowth \\
11 & E5a\&b without regrowth \\
\hline
\end{tabular}

Mature with unheighted regrowth ${ }^{\mathrm{a}}$

\begin{tabular}{ll}
12 & E1a\&b with unheighted regrowth \\
13 & E2a\&b with unheighted regrowth \\
14 & E+3a\&b with unheighted regrowth \\
15 & E-3a\&b with unheighted regrowth \\
16 & E4a\&b with unheighted regrowth \\
17 & E5a\&b with unheighted regrowth \\
\hline
\end{tabular}

Mature with silvicultural regeneration ${ }^{\mathrm{a}}$

\begin{tabular}{|c|c|}
\hline 18 & E1\&2 with regeneration \\
\hline 19 & $\mathrm{E}+3$ with regeneration \\
\hline 20 & E-3 with regeneration \\
\hline 21 & E4\&5 with regeneration \\
\hline \multicolumn{2}{|c|}{ Unaged regrowth with mature $\mathrm{b}^{\mathrm{b}}$} \\
\hline 22 & $\mathrm{ER} 4-6+\mathrm{E} 1$ \\
\hline 23 & $\mathrm{ER} 3+\mathrm{E} 1$ \\
\hline 24 & $\mathrm{ER} 1 \& 2+\mathrm{E} 1$ \\
\hline 25 & ER4-6 + E2 \\
\hline 26 & $\mathrm{ER} 3+\mathrm{E} 2$ \\
\hline 27 & $\mathrm{ER} 1 \& 2+\mathrm{E} 2$ \\
\hline 28 & $\mathrm{ER} 3 \& 4+\mathrm{E}+3$ \\
\hline 29 & $\mathrm{ER} 1 \& 2+\mathrm{E}+3$ \\
\hline 30 & $\mathrm{ER} 3+\mathrm{E}-3$ \\
\hline 31 & $\mathrm{ER} 1 \& 2+\mathrm{E}-3$ \\
\hline 32 & $\mathrm{ER} 1 \& 2+\mathrm{E} 4$ \\
\hline 33 & $\mathrm{ER} 1+\mathrm{E} 5$ \\
\hline
\end{tabular}

TABle 1: Continued.

\begin{tabular}{ll}
\hline $\begin{array}{l}\text { Forest } \\
\text { class }\end{array}$ & Forest class descriptor \\
\hline Pure unaged regrowth $^{c}$ & \\
34 & ER4-6/1 \\
35 & ER3/1 \\
36 & ER1\&2/1 \\
37 & ER4-6/2 \\
38 & ER3/2 \\
39 & ER1\&2/2 \\
40 & ER3\&4/+3 \\
41 & ER1\&2/+3 \\
42 & ER3/-3 \\
43 & ER1\&2/-3 \\
44 & ER1\&2/4 \\
45 & ER1/5 \\
\hline
\end{tabular}

Regrowth with silvicultural regeneration ${ }^{c}$

\begin{tabular}{ll}
46 & $\mathrm{ER} / 1 \& 2+$ regeneration \\
47 & $\mathrm{ER} /+3+$ regeneration \\
48 & $\mathrm{ER} /-3+$ regeneration \\
49 & $\mathrm{ER} / 4 \& 5+$ regeneration \\
\hline
\end{tabular}

Even-aged silvicultural regeneration ${ }^{\mathrm{d}}$

50

51

52

53

54

55

56

57

58

59

60

61

62

63

64

65

66

67

68

69 $\leq 1959$ regeneration/ 1 or 2

$\leq 1959$ regeneration/ +3 or $\mathrm{X}$

$\leq 1959$ regeneration/-3

$\leq 1959$ regeneration/4

1960s regeneration/1 or 2

1960s regeneration/+3 or $\mathrm{X}$

1960s regeneration/-3

1960s regeneration/4

1970s regeneration/ 1 or 2

1970 s regeneration/ +3 or $\mathrm{X}$

1970s regeneration/-3

1970s regeneration/4

1980s regeneration/ 1 or 2

1980s regeneration/+3 or $\mathrm{X}$

1980s regeneration/-3

1980s regeneration/4

1990s regeneration/ 1 or 2

1990s regeneration/+3 or $\mathrm{X}$

1990s regeneration/-3

1990s regeneration/4 
TABle 1: Continued.

\begin{tabular}{cl}
\hline $\begin{array}{l}\text { Forest } \\
\text { class }\end{array}$ & Forest class descriptor \\
\hline 70 & 2000 's regeneration/1 or 2 \\
71 & 2000 's regeneration/+3 or X \\
72 & 2000 's regeneration/-3 \\
73 & 2000 's regeneration/4 \\
74 & All regeneration/5 \\
\hline Unstocked ${ }^{\text {d }}$ & \\
75 & Some eucalypts/1\&2 \\
76 & Some eucalypts/+3 or X \\
77 & Some eucalypts/-3 \\
78 & Some eucalypts/4 \\
79 & Some eucalypts/5 \\
80 & Unstocked/1\&2 \\
81 & Unstocked/+3 or X \\
82 & Unstocked/-3 \\
83 & Unstocked/4 \\
84 & Unstocked/5 \\
\hline
\end{tabular}

Noneucalypt forest

Rainforest $\mathrm{t}^{\mathrm{e}}$

\begin{tabular}{ll}
85 & $\mathrm{M}+$ \\
86 & $\mathrm{M}-$ \\
\hline
\end{tabular}

Other native forest

\begin{tabular}{cl}
87 & Secondary Species \\
88 & Wattle \\
\hline Plantation & \\
89 & Hardwood Plantation \\
90 & Softwood Plantation \\
\hline
\end{tabular}

Nonforest

91 Scrub, Waste, Water, Sea

$92 \quad$ Unclassified

${ }^{a}$ Mature, Regrowth, and Silvicultural Regeneration refers to eucalypt forests. E denotes eucalypt and ER regrowth. Numbers in the Forest Class descriptor represent either mature or regeneration height, and letters denote mature crown density or regrowth eucalypt crown cover. Mature eucalypt height classes are: 1 (>55 m), $2(41-55 \mathrm{~m}),+3(34-41 \mathrm{~m}),-3(27-34 \mathrm{~m}), 4(15-$ $27 \mathrm{~m}), 5(<15 \mathrm{~m})$. Regrowth height classes are: $1(<15 \mathrm{~m}), 2(15-27 \mathrm{~m})$, $3(27-37 \mathrm{~m}), 4(37-44 \mathrm{~m}), 5(44-50 \mathrm{~m})$, and $6(>50 \mathrm{~m})$. Mature eucalypt crown density codes and \% crown cover are: a (70-100\%), b (40-70\%), c (20-40\%), and d (5-20\%). Regrowth eucalypt crown density codes and $\%$ crown cover are: a $(90-100 \%)$, b (70-90\%), c (50-70\%), and d (10$50 \%) .{ }^{b}$ ER denotes regrowth, and numbers denote regrowth height or height range. Ex describes mature eucalypt component. 'ER denotes regrowth, numbers denote regrowth height or height range, and/number describes regrowth height potential at maturity. ${ }^{\mathrm{d}}$ Silvicultural Regeneration with height potential of regeneration indicated after/, or unstocked regions with height potential when stocked with eucalypts indicated after/. X denotes unknown height potential. ${ }^{e}$ See Methods for description of rainforest Forest Classes on observed growth rates, recorded height of previous stands, and evidence of previous tree heights from standing dead trees, fallen trees, or clumps of remnant forest.

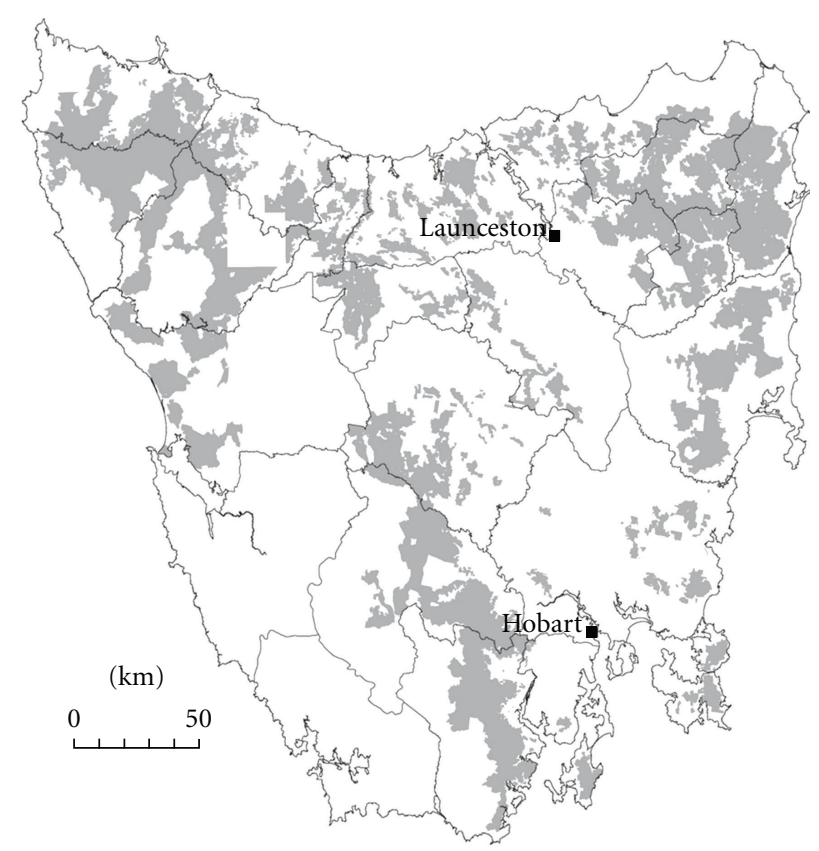

Figure 1: Tasmanian State forest and Inventory Management Areas. Shaded regions indicate land managed by Forestry Tasmania, excluding 1242 ha located on King Island, lines delineate the State into Inventory Management Areas.

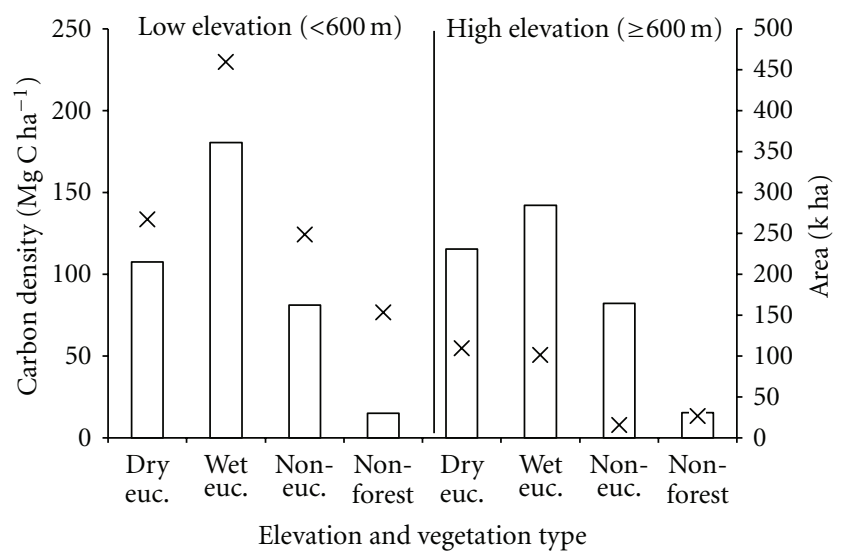

FIgure 2: Standing-tree C densities and areas by elevation and vegetation type in Tasmanian State forest. Bars denote $\mathrm{C}$ density, and crosses denote area.

Tree measurements from $>3500$ sample plots support the inventory and provide an excellent opportunity to estimate forest carbon stocks at the landscape level in Tasmania and estimate and explore Carbon Carrying Capacity of standing trees in Tasmanian State forest.

The objective of this work was to improve understanding of forest $\mathrm{C}$ stocks at the landscape level in Tasmanian State forest using an inventory-based analysis of $\mathrm{C}$ in standing live and dead trees, and examine carbon in forest by Forest Class, forest type, elevation, and land-use classes.

We also estimate the Carbon Carrying Capacity of Tasmanian State forest and explore the methods required to 
TABLE 2: Error in area weighted estimates of forest carbon density within forest classes containing measured eucalypt forests between Inventory areas (Standard error of the mean as a percentage of the mean).

\begin{tabular}{lccccccccc}
\hline Forest class & Error & Forest class & Error & Forest class & Error & Forest class & Error & Forest class & Error \\
\hline 1 & 15.0 & 14 & 6.6 & 27 & 5.5 & 40 & 6.1 & 53 & 6.1 \\
2 & 6.8 & 15 & 2.8 & 28 & 4.5 & 41 & 10.0 & 54 & 7.4 \\
3 & 6.3 & 16 & 5.7 & 29 & 7.6 & 42 & 8.9 & 55 & 11.8 \\
4 & 6.9 & 17 & 0.0 & 30 & 10.6 & 43 & 12.1 & 56 & 10.7 \\
5 & 9.8 & 18 & 14.4 & 31 & 8.1 & 44 & 0.8 & 58 & 6.0 \\
6 & 9.7 & 19 & 8.8 & 32 & 4.6 & 45 & 0.0 & 59 & 8.0 \\
7 & 2.7 & 20 & 11.2 & 33 & 8.8 & 46 & 12.0 & 60 & 3.5 \\
8 & 6.5 & 21 & 22.1 & 34 & 3.8 & 47 & 10.1 & 61 \\
9 & 6.0 & 22 & 2.1 & 35 & 6.8 & 48 & 22.6 & 62 \\
10 & 3.0 & 23 & 10.3 & 36 & 3.2 & 49 & 26.3 & 63 \\
11 & 4.4 & 24 & 0.0 & 37 & 4.1 & 50 & 21.9 & 64 \\
12 & 0.0 & 25 & 0.4 & 38 & 6.0 & 51 & 13.3 & 8.2 \\
13 & 7.9 & 26 & 0.3 & 39 & 6.4 & 52 & 11.0 & 65 \\
\hline
\end{tabular}

TABLE 3: Areas of forest cover types for each land-use category on Tasmanian State forest. All figures are \% area.

\begin{tabular}{lccccccc}
\hline Land-use class & $\begin{array}{c}\text { Wet } \\
\text { mature } \\
\text { eucalypt }\end{array}$ & $\begin{array}{c}\text { Dry } \\
\text { mature } \\
\text { eucalypt }\end{array}$ & $\begin{array}{c}\text { Wet } \\
\text { regrowth } \\
\text { eucalypt }\end{array}$ & $\begin{array}{c}\text { Dry } \\
\text { regrowth } \\
\text { eucalypt }\end{array}$ & $\begin{array}{c}\text { Rain- } \\
\text { forest }\end{array}$ & $\begin{array}{c}\text { Other } \\
\text { forest }\end{array}$ \\
\hline Couped forest & 19 & 15 & 41 & 11 & 7 & 3 & 7 \\
Uncouped & 12 & 18 & 16 & 7 & 6 & 11 & 7 \\
Formal reserve & 14 & 26 & 9 & 6 & 29 & 5 & 5 \\
Informal reserve & 17 & 25 & 12 & & 6 & 11 \\
\hline
\end{tabular}

achieve and maintain Carbon Carrying Capacity in Tasmanian State forest.

\section{Methods}

Below, we first describe Tasmanian State forest and then the portion of State forest examined here followed by descriptions of various State forest stratifications significant to the processes of estimating standing tree volumes. We then describe how standing tree volumes are estimated, how standing tree $\mathrm{C}$ stocks are estimated from standing tree volumes and lastly how the ecological and land-use divisions of State forest within which standing tree C-stocks will be estimated.

\subsection{Tasmanian State Forest Description. Forestry Tasmania} is a government business enterprise with statutory responsibility for management of $1.5 \mathrm{M}$ ha of Tasmania's land (State forest), of which 1.3 M ha is forested, corresponding to $39 \%$ of Tasmania's forests. The Tasmanian Parks and Wildlife Service manages another $2.6 \mathrm{M}$ ha of public land, mostly as national parks and conservation reserves, which contain 1.4 M ha of forests [14]. A further $0.9 \mathrm{M}$ ha of forest is located on private land in Tasmania [15]. The $1.5 \mathrm{M}$ ha of State forest is distributed throughout Tasmania (Figure 1) and is divided into land-use classes including land in and outside of reserves, described in detail below. Of State forest area, $0.52 \mathrm{M}$ ha is located in reserves and a further $0.31 \mathrm{M}$ ha of unreserved native forest is outside wood production areas, leaving $0.69 \mathrm{M}$ ha of State forest as native forest available for wood production [16]. Forestry Tasmania is legislated (Section 22AA of the Forestry Act 1920) to make available $0.3 \mathrm{M} \mathrm{m}^{3}$ year $^{-1}$ of high-quality eucalypt veneer and sawlogs. Roughly $2.2 \mathrm{Tg}$ of lower-quality logs arise from the harvests required to produce the high-quality logs [16].

Vegetation types in Tasmanian State forest include scrub, rainforest, wet Eucalyptus (eucalypt) forest and dry eucalypt forest. Eucalypt forests in Tasmania attain average heights at maturity from $>55 \mathrm{~m}$ to $<15 \mathrm{~m}$ [17] as there is a broad range of forest and productivity types. The simplest division is into wet and dry eucalypt forests, which are effectively differentiated by tree height in Tasmania [18]. Dry eucalypt forests tend to be restricted to mature tree heights $<34 \mathrm{~m}$ while wet eucalypt forests tend to attain heights $\geq 34 \mathrm{~m}$, and State inventory divides forests based on these height classes [17]. Productivity of eucalypt forests ranges from $\sim 1 \mathrm{~m}^{3} \mathrm{ha}^{-1}$ year $^{-1}$ in dry eucalypt forests [19] to $\sim 10 \mathrm{~m}^{3} \mathrm{ha}^{-1}$ year $^{-1}$ in wet eucalypt forests [20]. Elevation is also a significant factor, with species dominance often changing at elevations of $\sim 600 \mathrm{~m}[21,22]$. Vegetation cover type in Tasmania is also temporally variable. Notably, wet eucalypt forests succeed to mixed forest (with an eucalypt overstorey and a rainforest understorey) then to rainforest in the absence of fire $[23,24]$, while mixed forests and rainforests are converted back to eucalypt forests following wildfire wherever nearby eucalypt seed sources exist or are 
applied [25]. Variability in forest dynamics over space, and time is often overlooked in calculations of landscape C dynamics.

This paper only examines native vegetation types on Tasmanian State forest, excluding softwood and hardwood plantations from analysis. Plantations contain only a small proportion $(<5 \%)$ of State forest C (MBAC [26]). Furthermore, plantations and native forests are generally analysed by different systems, with native forest growth and yield estimates based on Forest Class, and plantation growth and yield based on other factors such as species, year of establishment, and silvicultural regime, making integration problematic. Insufficient data across the estate was available to meaningfully estimate other forest $\mathrm{C}$ pools (soil, woody debris, litter); hence, this paper only deals with $\mathrm{C}$ in live and dead standing trees (bole, branches, foliage, and roots) and C stock estimates are only for standing trees unless otherwise stated.

2.2. Stratification of State Forest. State forest is stratified in several ways, into Blocks, Inventory Management Areas, Photo-Interpretation Types, Strata, and Forest Classes. Blocks are typically 2000 to 20000 ha bounded by major rivers, roads, or ridge-lines. Inventory Management Areas comprise contiguous and discrete groups of Blocks occurring in a similar environment and supporting common forest types that are expected to grow at a similar rate. State forest is divided into 21 Inventory Management Areas (Figure 1). Forest within and among Blocks and Inventory Management Areas are mapped to $>14000$ PhotoInterpretation Types based on forest characteristics observed from aerial photographs. Photo-Interpretation Types are in turn grouped into 91 Forest Classes on the basis of similarities in merchantable timber volume and growth characteristics [17, 27]. Each Inventory Management Area and Forest Class combination forms a Stratum. Forest Classes are dominated by eucalypt forest types (Table 1), however, there are also Forest Classes covering rainforest, other noneucalypt native forest (e.g., Acacia species), plantations, and non-forest (e.g., water bodies and scrub which includes button grass (Gymnoschoenus sphaerocephalus; Table 1)). There was no Forest Class 57 or 78 in State forest in 2009. Areas of the State forest occupied by scrub, waste or water (Forest Class 91) were assumed to contain no standing trees or associated C. This study is based on estimates of total standing tree volume at the Forest Class level in 2009.

2.3. Standing Tree Volume Estimates. Total standing tree volume (standing gross bole volume) was estimated from sample plot data collated in 2007 from $>3500$ permanent and temporary inventory plots. Standing gross bole volume of all eucalypt trees with diameter at breast height $(1.3 \mathrm{~m})>10 \mathrm{~cm}$ and all non-eucalypt species with diameter at breast height $>20 \mathrm{~cm}$ were measured in either 0.1 ha or 0.2 ha plots using a variety of protocols based on diameter at breast height and total tree height.

Stratum level volume over age yield curves were derived using an empirical stand level growth model (unpublished,
Forestry Tasmania). The use of plots for sustainable yield estimation is described in Whiteley [27]. This model simulates stand-level growth in each inventory plot over time and apportions this growth to measured trees. Stratumlevel yield curves represent the average of plot-level yield curves collected from the available plots located in each stratum. Yield was calculated from the volume over age curves for all forests at 2009. Total standing-tree volume at 2009 for each Forest Class was derived as the area-weighted average standing-tree volume of all strata comprising each Forest Class, whether summed to entire State forest or any portion thereof (individual Forest Classes, Forest Classes encompassing mature, regrowth or silvicultural regeneration forests, non-eucalypt vegetation types, land-use classes, wet eucalypt forests, dry eucalypt forests or by elevation; all described in further detail below).

Eucalypt Forest Classes are subdivided into mature, regrowth, and silvicultural regeneration. The inventory differentiates forest as mature or immature by forest age, where mature forests are comprised of predominantly mature trees estimated to be $\geq 110$ years old. This differentiation separates forests by early pole form and older branched form reasonably well at the landscape level and reflects the age class structure of State forest with most forests being considerably younger or older than 110 years. Regrowth consists of trees estimated to be predominantly $<110$ years old but the actual age of which is unknown and largely regenerated following wildfire [17]. Silvicultural regeneration is of known age, most regenerating following harvesting since 1950 with some of wildfire origin where the year burned is known. Forests are also divided into height and crown-cover (proxy for tree density) classes, described in Table 1 legend. Both eucalypt silvicultural regeneration and eucalypt regrowth classes are assigned height potentials, representing the height that regrowth or silvicultural regeneration is expected to attain at maturity. Potential height is based on observed growth rates, recorded height of previous stands, and evidence of previous tree heights from standing dead trees, fallen trees, or clumps of remnant forest.

A large area of State forest is comprised of non-eucalypt forest including rainforest, Acacia species, and scrub. Rainforests were divided into two groups based on site fertility, structure and floristics. The more productive, taller $(>25 \mathrm{~m})$ rainforest is referred to as "Callidendrous and Thamnic rainforest occurring on fertile sites" after [28-30] and was allocated to Forest Class 85. Less productive, shorter rainforest, referred to as "Thamnic rainforest on less fertile sites," was allocated to Forest Class 86. State forest contains roughly equivalent areas of rainforests in Forest Classes 85 and 86, with 98000 ha of Forest Class 85 and 105000 ha of Forest Class 86.

2.4. Standing Tree C Stocks. Since silvicultural regeneration established in the 1990s and 2000s (approximately 0.03 M ha each) is not yet of sufficient size for routine tree measurement, these stands are not assigned volumes. For this analysis, we assume silvicultural regeneration established in the 1990s had half the bole volume of silvicultural regeneration 


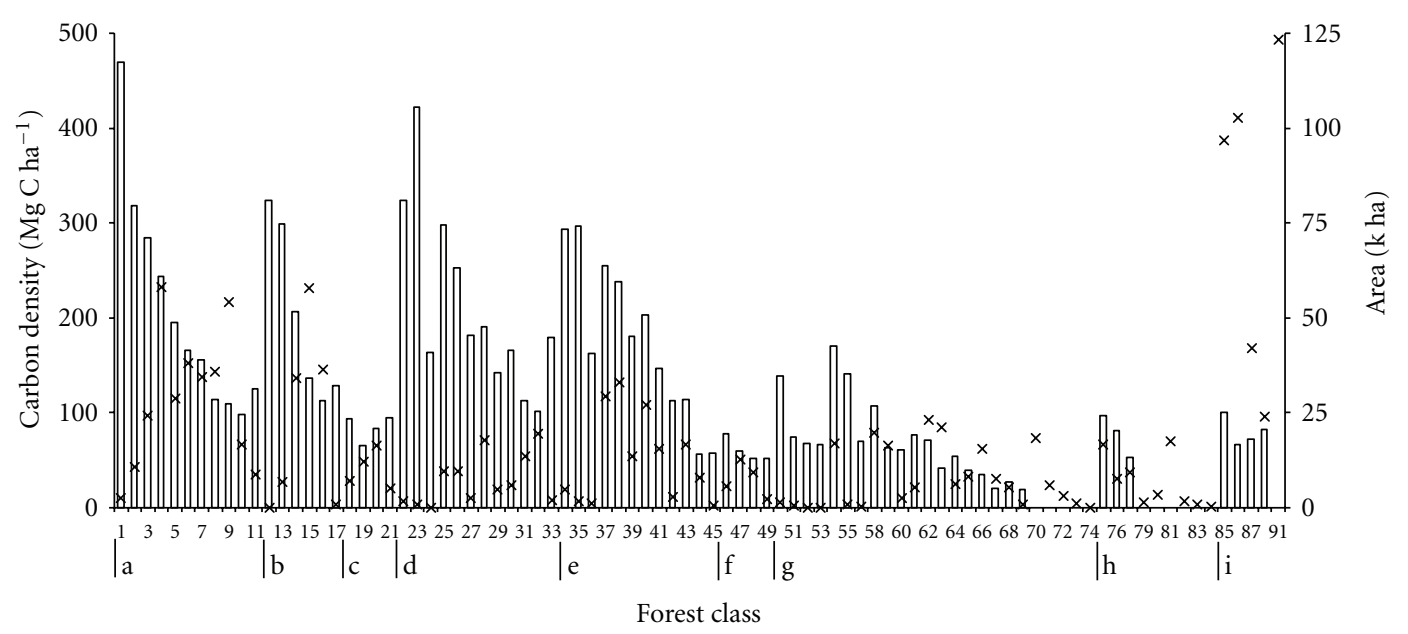

Figure 3: Areas and standing-tree carbon densities of Forest Classes in Tasmanian State forest. Forest Classes 57, 78, 89, and 90 are omitted. For a more complete description of Forest Classe, refer to Table 1. Bars denote carbon density, crosses denote area. a: mature eucalypt, b: mature eucalypt with unheighted regrowth, c: mature eucalypt with silvicultural regeneration, d: unaged eucalypt regrowth with mature eucalypt, e: pure unaged regrowth eucalypt, f: regrowth eucalypt with silvicultural regeneration, g: even aged eucalypt silvicultural regeneration, h: unstocked, and i: noneucalypt forest.

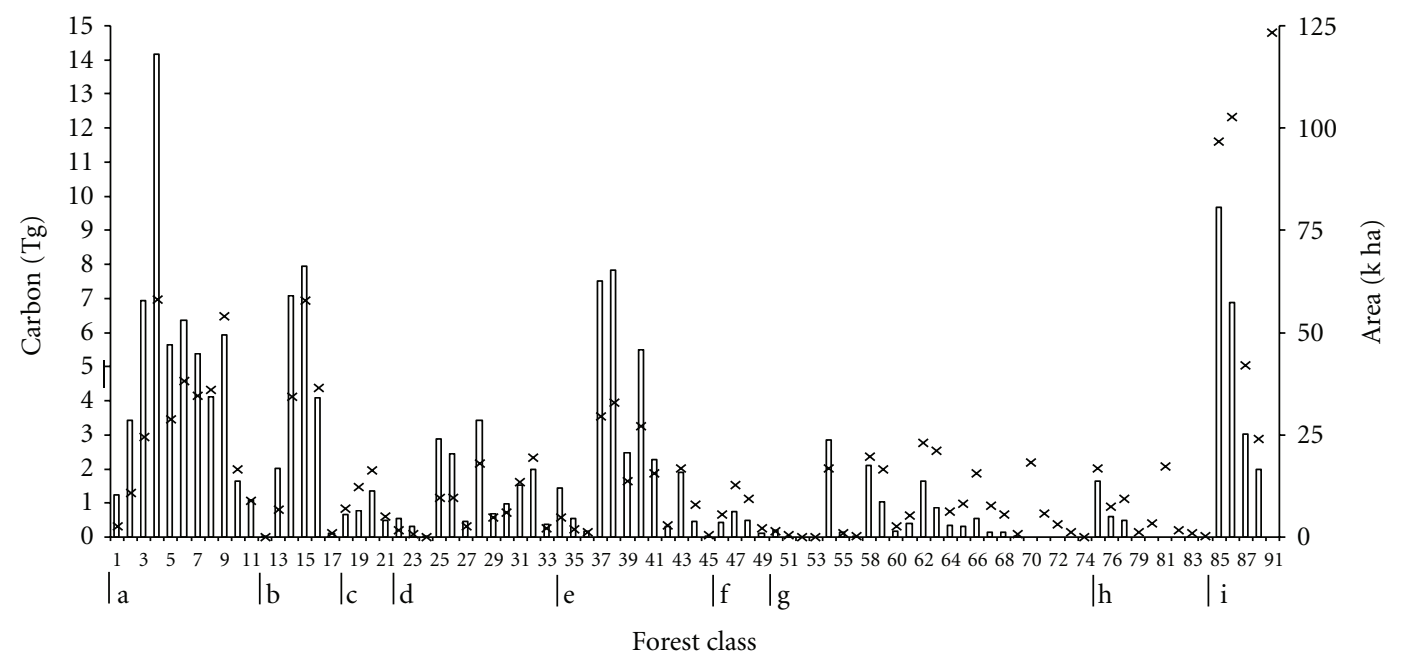

FIGURE 4: Areas and amount of carbon stored in standing trees in Forest Classes in Tasmanian State forest. Forest Classes, 57, 78, 89, and 90 are omitted. For a more complete description of Forest Classes refer to Table 1. Bars denote carbon, crosses denote area. a: mature eucalypt, b: mature eucalypt with unheighted regrowth, c: mature eucalypt with silvicultural regeneration, d: unaged eucalypt regrowth with mature eucalypt, e: pure unaged regrowth eucalypt, f: regrowth eucalypt with silvicultural regeneration, g: even aged eucalypt silvicultural regeneration, h: unstocked, and i: noneucalypt forest.

established in the 1980s and silvicultural regeneration established in the 2000s was conservatively assumed to have no volume. For unstocked or understocked forest and native non-eucalypt, forest standing-tree volumes are derived from expert opinion because little tree measurement data is available. Unstocked forests represent regions where productive forests are considered possible but remain unstocked for a range of reasons (e.g., failed silvicultural regeneration following natural or anthropogenic disturbance, pests, and diseases) and are uneconomical to restock.

Standing-tree bole volumes are converted to forest Cmass as described below. Bole volumes of all standing living and dead trees of all species were multiplied by a basic density of $500 \mathrm{~kg} \mathrm{~m}^{-3}$ [31] allowing biomass to be estimated. Total above-ground live-tree biomass (bole, branches and foliage) was estimated from live bole biomass by multiplying by an expansion factor of 1.46 [32]. Root biomass was included by multiplying total above-ground biomass by 1.25 . Dead trees were considered to comprise bole and roots only. Tree biomass was assumed to be half $\mathrm{C}$ [32]. Since expansion factors for total above-ground biomass and root biomass, as well as wood density and carbon content, are multiplicative, any $\%$ change in these factors will result in an equivalent change in estimates of standing forest carbon stocks. Sample 


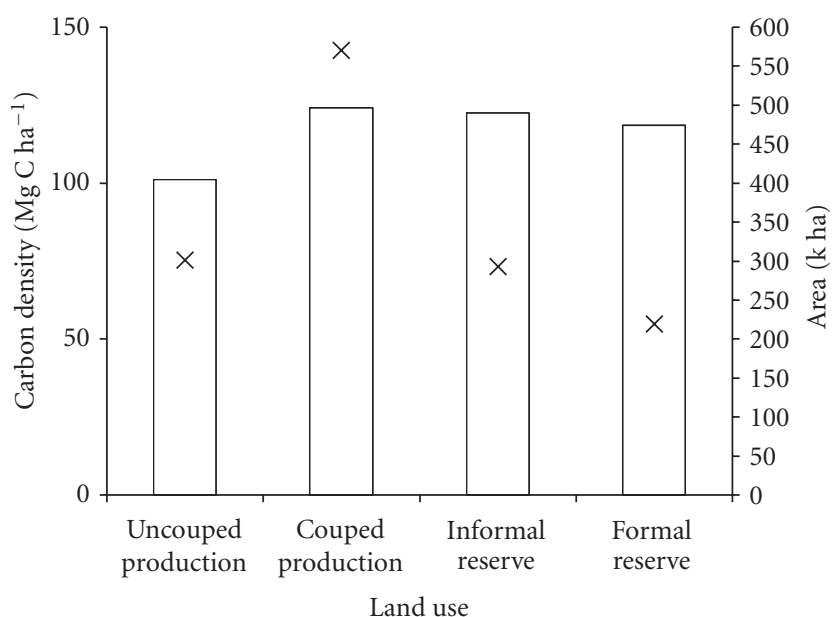

FIGURE 5: Standing-tree C density and area by land-use class in Tasmanian State forest. Bars denote C density, and crosses denote area.

plots (described above) were allocated to forests supporting eucalypts. Little to no data was available for noneucalypt dominated forests or nonmerchantable biomass components of eucalypts. These data gaps require further study to confirm or form the basis to revise factors that convert standing bole volumes to $\mathrm{C}$ mass described above.

2.5. Tasmanian State Forest Stratification. Tasmanian State forest is divided into four land-use classes: formal reserves, informal reserves, couped production forest, and uncouped production forest. Both formal and informal reserves on State forests form part of Tasmania's Comprehensive, Adequate and Representative Reserve system defined by the Tasmanian Regional Forest Agreement [33]. Formal reserves on State forests require dedication and revocation by the Tasmanian Parliament, whereas informal reserves are designated by Forestry Tasmania. Informal reserves often protect specific conservation values such as wedge-tailed eagle (Aquila audax) nest exclusion zones, wildlife habitat strips, and view-sheds, and their boundaries can only be modified by following rigorous procedures that require conservation values to be maintained on the landscape. A coupe is an operational treatment unit, typically used to refer to a harvest/reestablishment area, and couped production forests are those areas likely to be available for harvesting, though some may not be harvested. Not all forest within a coupe is harvested, with trees left behind for a range of reasons [27] including requirements to meet the Forest Practices Code [34]. On average, $\sim 25 \%$ of the area of harvested coupes is retained as unharvested forest [35], although the proportion unharvested is highly variable among coupes. Uncouped production forest represents those areas mapped within Forestry Tasmania's Provisional Coupe System but identified as unlikely to be, or not, available for harvesting. Factors that exclude forests in both couped and uncouped forests from harvesting include steep slopes, erodible soils, or difficulty or economics of access.
Eucalypt forests were divided into wet and dry forests based on mature tree height or potential height at maturity (dry eucalypt Forest Classes attain heights $<34 \mathrm{~m}$, and wet eucalypt Forest Classes attain heights $\geq 34 \mathrm{~m}$; [18]). State forest was also divided into high-elevation $(\geq 600 \mathrm{~m})$ and low-elevation $(<600 \mathrm{~m})$ elevation classes based on the average elevation of all coupes within each Block.

\section{Results}

The total mass of $\mathrm{C}$ in live and dead standing trees in State forest was $163 \mathrm{Tg}$. State forest comprises dry and wet eucalypt forest, noneucalypt forest, and non-forest, and includes $0.38 \mathrm{M}$ ha of dry eucalypt forest and $0.56 \mathrm{M}$ ha of wet eucalypt forest, respectively (Figure 2). The amount of standing-tree C was highest for wet eucalypt forest $(97 \mathrm{Tg})$, followed by dry eucalypt forests $(41 \mathrm{Tg})$, noneucalypt forest (22 Tg C), and non-forest (2 Tg C, Figure 2).

The area-weighted landscape average carbon density of Tasmanian State Forest was $123 \mathrm{MgCha}^{-1}$, including all forest, unstocked and non-forest land. Solely forested land contained $133 \mathrm{MgCha}^{-1}$. Never commercially harvested forests contained $155 \mathrm{MgCha}^{-1}$. Dry forests contained $118 \mathrm{MgCha}^{-1}$. Wet forests (eucalypt and noneucalypt) contained $185 \mathrm{MgC} \mathrm{ha}^{-1}$ and wet eucalypt forest only contained $222 \mathrm{MgC} \mathrm{ha}^{-1}$. Mature eucalypt forests contained $179 \mathrm{MgCha}^{-1}$, with mature dry eucalypt forests containing $121 \mathrm{MgCha}^{-1}$ and mature wet eucalypt forests containing $232 \mathrm{MgCha}^{-1}$.

Tasmanian State forest able to achieve 289 tonnes carbon $\mathrm{ha}^{-1}$ of live biomass (the average Carbon Carrying Capacity of south-east Australian forests from [10] is restricted to forest classes $1-3$, that currently occupy $\sim 2.5 \%$ Tasmanian State forest area. Only $\sim 10-15 \%$ of State forest area is estimated to have the potential to achieve this amount of biomass at some stage of the disturbance cycle.

Forest Classes supporting taller eucalypts and eucalypts with greater crown cover had higher $\mathrm{C}$ densities $\left(\mathrm{C} \mathrm{ha}^{-1}\right.$; Figure 3; Table 1). The highest $\mathrm{C}$ density among Forest Classes occurred in the tallest $(>55 \mathrm{~m})$, greatest crown cover $(>40 \%)$, mature wet eucalypt forests with neither regrowth nor silvicultural regeneration (Forest Class 1, an average of $470 \mathrm{MgCha}^{-1}$, Figure 3, Table 1). The other mature eucalypt Forest Classes with neither regrowth nor silvicultural regeneration (Forest Classes 2-11) contained $21-68 \%$ the C density of Forest Class 1. Mature eucalypt forests with regrowth or silvicultural regeneration had higher $\mathrm{C}$ densities when tall mature or regenerated forests were present (e.g., up to $422 \mathrm{MgCha}^{-1}$ in Forest Class 23, which contained significant mature tall trees typical of Forest Classes 1-2, Figure 3, Table 1). From 56 inventory plots located in forests supporting mature trees $>55 \mathrm{~m}$ tall (Forest Class 1 and 2), live standing-tree $\mathrm{C}$ (including branches, bark and roots) averaged $387 \mathrm{MgCha}^{-1}$ with a range of 22-935 $\mathrm{Mg} \mathrm{Cha}^{-1}$. Variability in area-weighted estimates of forest carbon density within Forest Class between Inventory area are presented in Table 2. 
Total C stocks in any portion of a forest estate, such as Forest Class, land-use class, vegetation type, or elevation class, are a function of both forest $\mathrm{C}$ density and forest area. Mature eucalypt cover types without silvicultural regeneration or regrowth of heights $>55 \mathrm{~m},>41-55 \mathrm{~m},>34-41 \mathrm{~m}$, $>27-34 \mathrm{~m},>15-27 \mathrm{~m}$ and $\leq 15 \mathrm{~m}$ (Table 1) are represented by $13,82,67,70,71$, and 9 thousand ha in State forest, respectively. In 2009, State forest contained 2600 ha of the highest crown cover $(>40 \%)$, tallest $(>55 \mathrm{~m}$ ) eucalypt cover type (Forest Class 1, Figure 1), representing only $0.2 \%$ of State forest by area. Mature forests containing $>55 \mathrm{~m}$ tall trees total 13400 ha (Forest Class 1 and 2, Table 1).

Overall, the largest stock of $\mathrm{C}$ in mature eucalypt forests without regrowth or silvicultural regeneration is present in $>41-55 \mathrm{~m}$ forest $(21.6 \mathrm{Tg} \mathrm{C}$, Table 1$)$ then $>34-41 \mathrm{~m}(11.8 \mathrm{Tg}$ C), $>27-34 \mathrm{~m}(9.5 \mathrm{Tg} \mathrm{C}),>15-27 \mathrm{~m}(7.4 \mathrm{Tg} \mathrm{C}),>55 \mathrm{~m}(5.2 \mathrm{Tg}$ C), and $\leq 15 \mathrm{~m}$ (1.1 Tg C) tall forests, with tallest eucalypt forest of greatest crown cover (Forest Class 1) containing only $1.3 \mathrm{Tg} \mathrm{C}$ (Figure 4 ). In addition to mature forest, State forest also contains silvicultural regeneration and regrowth forests where height potential at maturity is estimated. The area of State forest that currently supports or has the potential to support mature forests in these height classes represents $24,315,269,222,156$, and 14 thousand ha of State forest, respectively. Those components that are not mature are capable of sequestering additional $\mathrm{C}$ into standing trees.

Overall, silvicultural regeneration and regrowth forests contained significant amounts of standing-tree $\mathrm{C}$, with more $\mathrm{C}$ generally found in older, taller, and greater crowncover regrowth and silvicultural regeneration forests, or those forests with a larger mature component. Forests with a mature component and including regrowth or silvicultural regeneration contained a total of $81.5 \mathrm{Tg}$ C. Regrowth forests including those with silvicultural regeneration contained 46.6 Tg C, while forests containing solely silvicultural regeneration contained $13.3 \mathrm{Tg}$ C. Forests regenerating following silviculture before 1959 and in the 1960s, 1970s, 1980s, and 1990 s are represented by Forest Classes 50-53, 54-57, 58$61,62-65$, and 66-69, respectively (Figure 3, Table 1). Within these five age-classes, $C$ density ranged between 67-139, 70-170, 63-107, 39-71, and 19-35 $\mathrm{MgC} \mathrm{ha}^{-1}$, respectively. Generally, older silvicultural regeneration contained higher $\mathrm{C}$ densities. Within each age range, larger $\mathrm{C}$ densities occurred in forests with greater potential height at maturity, reflecting site characteristics.

Significant amounts of C are also found in non-eucalypt native forest. Rainforests across State forest were estimated to contain 16.8 Tg C, while other native forests (not eucalypt or rainforest) were estimated to contain $4.9 \mathrm{Tg} \mathrm{C}$. Rainforest $\mathrm{C}$ densities were estimated to be $100 \mathrm{Mg} \mathrm{Cha}^{-1}$ for Forest Class 85 and $67 \mathrm{MgCha}^{-1}$ for Forest Class 86 (Table 1). Other non-eucalypt native forests included in Forest Classes 87-88 were estimated to contain 72 and $83 \mathrm{MgC} \mathrm{ha}^{-1}$, respectively.

Most (82\%) State forest is below $600 \mathrm{~m}$ in elevation (Figure 2). Carbon densities calculated for standing trees in low-elevation $(<600 \mathrm{~m})$ and high-elevation $(\geq 600 \mathrm{~m})$ dry eucalypt forests were similar. However, the $\mathrm{C}$ density of standing trees in low-elevation wet eucalypt forests ranked above that of high-elevation wet eucalypt forests, and in general wet eucalypt forests $\mathrm{C}$ densities ranked above dry eucalypt forest C-density. The $\mathrm{C}$ densities of low- and highelevation rainforest or non-forest cover types were similar.

The relative contributions to State forest $\mathrm{C}$ from uncouped production forest, couped production forest, informal reserve, and formal reserve forests are $20 \%, 42 \%$, $16 \%$ and $22 \%$, respectively, which is almost identical to the proportion by area of the estate occupied by these categories since all have similar average C densities (101$124 \mathrm{Mg} \mathrm{C} \mathrm{ha}^{-1}$; Figure 5 ). The $\mathrm{C}$ stocks of standing trees were $30,71,36$, and $26 \mathrm{Tg} \mathrm{C}$ for uncouped production, couped production, informal reserve, and formal reserve forests, respectively. Thus, differences in area for each land-use class largely explain differences in $\mathrm{C}$ stocks.

Unsurprisingly, formal and informal reserves contain the largest proportion of mature forests (40-42\%) and rainforests (20-29\%), while uncouped forests contained the largest proportion of non-forest and couped forests contained the largest proportion of regrowth and regenerating forests $(52 \%$, Table 3$)$. Uncouped forests contained a relatively large proportion of mature forests (30\%) with 53\% of the area being eucalypt forest. The reserves were $55-60 \%$ eucalypt forest, with the couped forest $86 \%$ eucalypt forest.

If we assume all eucalypt forests can be managed to maturity simultaneously, achieving their height potential with highest possible crown cover, we can estimate Theoretical C Saturation [11] for the eucalypt component of State forest. Theoretical C Saturation is the highest C density possible for a given area of land, being standing-tree $C$ density in this study. Currently, the eucalypt estate is estimated to contain $139 \mathrm{Tg}$ C. If the eucalypt estate could be managed to be simultaneously mature, increasing merchantable volumes and, hence, $\mathrm{C}$ mass, to the maximum described by Forestry Tasmania's forest yield curves, an additional $65 \mathrm{Tg} C$ could be sequestered into State forest. Thus, the eucalypt estate was at $69 \%$ of this Theoretical C Saturation in 2009. If rainforests and other non eucalypt native forests, which contained $22 \mathrm{Tg}$ $\mathrm{C}$ in 2007, are included and assumed to already be at $\mathrm{C}$ saturation, total State forest was at $72 \%$ of its Theoretical C Saturation in 2009.

Rainforests were estimated to contain only $34-41 \%$ of the $\mathrm{C}$ density of wet eucalypt forests, when comparing Forest Class 85 and 86 rainforests with Forest Class 4 and 5 eucalypt forests, respectively. If all the wet eucalypt forest succeeded to rainforest with a $\mathrm{C}$ density intermediate between that of Forest Classes 85 and $86\left(83 \mathrm{MgCha}^{-1}\right)$, there would be a loss of $50 \mathrm{Tg} \mathrm{C}$ from State forest. Conversely, if we assume Forest Class 85 rainforest could be converted to Forest Class 4 eucalypt forest and Forest Class 86 rainforest could be converted to Forest Class 5 eucalypt forest (Table 1), an additional $28 \mathrm{Tg} \mathrm{C}$ would be added to State forest.

\section{Discussion}

The tallest eucalypt forests contained the largest $\mathrm{C}$ densities in State forest. From 56 inventory plots located in forests supporting mature trees $>55 \mathrm{~m}$ tall (Forest Classes 1 and 2), live standing-tree $\mathrm{C}$ (including branches, bark, and roots) 
averaged $387 \mathrm{MgCha}^{-1}$, with a range of 22 to $935 \mathrm{MgCha}^{-1}$. Lower $\mathrm{C}$ densities occur in tall forests with low crown cover where randomly located plots encountered few largedimensioned trees. Very C-dense forests in south-eastern Australia contain the nation's largest trees and have recently attracted attention for their large biomass density. Keith et al. [7] summarise above-ground living biomass estimates for some of southern Tasmania's tall E. obliqua and E. regnans forests as $444-752 \mathrm{Mg} \mathrm{Cha}^{-1}$ and present results for E. regnans forests in the O'Shannassy catchment of Victoria that had 104-1819 Mg C (live above-ground biomass) ha ${ }^{-1}$ before the wildfires in February 2009 which burned 93\% of the O'Shannassy catchment [36]. Thirteen of these sites $>100$ years of age supported an average of $1053 \mathrm{MgC}$ (live aboveground biomass) ha ${ }^{-1}$. Tasmania's tall ( $>55 \mathrm{~m}$ ) State forest, therefore, contains standing-tree $\mathrm{C}$ densities in the range reported by Keith et al. [7] for the O'Shannassy catchment in Victoria, but the most C-dense forest measured in Tasmanian State forest had a $\mathrm{C}$ density half the maximum in the O'Shannassy catchment.

The area-weighted landscape average carbon density of never commercially harvested forests contained $155 \mathrm{Mg} \mathrm{Cha}^{-1}$, just 54\% of the Keith et al. [10] and Mackey et al. [8] estimate of average Carbon Carrying Capacity for south-eastern Australian forests. Of never commercially harvested eucalypt forests in Tasmania, $58 \%$ by area contained immature regrowth due to the effect of past wildfire (Figure 3 ) and thus would be below Carbon Carrying Capacity as calculated by the above authors. However, even solely mature eucalypt forests contained just $62 \%$ of the above estimate of average south-eastern Australian forest Carbon Carrying Capacity. Additionally, just $2.5 \%$ of Tasmanian State forest had achieved this carbon density in 2009 with only $10-15 \%$ thought to be able to achieve it at some stage of the disturbance cycle. Estimates of forest carbon density in Victorian State forest for all forest was $96 \mathrm{MgC} \mathrm{ha}^{-1}$ [37], with production forests containing $136 \mathrm{Mg} \mathrm{Cha}^{-1}$ (Norris, J. personal communication). These data indicate the Mackey et al. [8] and Keith et al. [10] estimates of Carbon Carrying Capacity are too high, and measured landscape level forest carbon stocks in south-eastern Australia are within the range of temperate forest carbon stocks presented in IPCC [13].

State forest is comprised of a wide range of productivity and vegetation types. While the most C-dense forests, the tallest forests with greatest crown cover (Forest Class 1), have attracted much attention [5-8], these forests comprise 2600 ha, $0.2 \%$ State forest by area. The shorter eucalypt forests or those with lower crown cover (Forest Class 2-11) have considerably lower C densities, $21 \%-68 \%$ of Forest Class 1 eucalypt forest. Non-eucalypt forests (rainforest and other non-eucalypt native species) have $\mathrm{C}$ densities estimated to be $14-21 \%$ of Forest Class 1, and scrub (Forest Class 91) far less still. This wide diversity in $C$ densities among eucalypt forests and between vegetation types in State forest, or indeed any forest estate, needs to be considered when discussing $\mathrm{C}$ storage and dynamics at the estate or landscape level. Old carbon dense forests have been taken as the reference point to compare forest carbon stocks against those in Australia [4-7] and internationally [38-40]. These are not the best reference point when evaluating landscape carbon dynamics. Carbon losses from forest management will be greatly overestimated if managed landscapes are compared to the potential maximum $\mathrm{C}$ content achieved only if all individual stands are at their maximum $\mathrm{C}$ content at the same time [12].

Low-elevation $(<600 \mathrm{~m})$ and high-elevation $(\geq 600 \mathrm{~m})$ dry eucalypt forests are structurally similar (Duncan and Brown [41]); hence, it is not surprising that they have similar $\mathrm{C}$ densities (Figure 2). The $\mathrm{C}$ densities of low-elevation wet eucalypt forest ranked above $\mathrm{C}$ densities of high-elevation wet eucalypt forests. Wet eucalypt forests are generally taller at low elevations, and in Tasmania predominantly comprise E. obliqua, although some areas are dominated by the large, iconic E. regnans forests, while elevated wet eucalypt forests are predominantly E. delegatensis [22].

The Australian and Tasmanian governments, through the Regional Forest Agreement [30] and the Tasmanian Community Forest Agreement [42], have set aside significant amounts of mature and regrowth forest in formal and informal reserves. This has resulted in the reserve system on State forest containing roughly equivalent $\mathrm{C}$ densities (averages of $119-122 \mathrm{MgCha}^{-1}$, Table 3 ) to couped production forest $\left(124 \mathrm{MgC} \mathrm{ha}^{-1}\right)$. Uncouped production forests also contain significant mature and regrowth eucalypt forest and, despite containing a large proportion of non-forest $(29 \%$ of the estate area), the uncouped production forest area has a similar average $\mathrm{C}$ density of $101 \mathrm{Mg} \mathrm{Cha}^{-1}$. These landscapelevel values are within the range reported for temperate forests from around the world by IPCC [13].

Recently in Australia, emphasis has been placed on estimating and storing the maximum amount of $\mathrm{C}$ in forests, sometimes described by the parameter "Carbon Carrying Capacity" [6-8]. This has resulted in a focus on the C content of south-eastern Australian hardwood forest stands that contain some of the largest trees in the world and thus, very large $C$ densities. Large areas of forest estates have been assumed to comprise or be capable of growing such very tall eucalypt forests. The Tasmanian State forest data show that such forests comprise only a small proportion of total forest area. Furthermore, the prevalence of fire in the Australian landscape will limit our ability to store carbon on the landscape at any one time. Thus "Carbon Carrying Capacity" estimated by measuring the carbon content of old carbon dense forests such as those of Roxburgh et al. [6] without representation of younger age classes and seral stages is equivalent to Theoretical C Saturation [11], and Theoretical C Saturation is a much more appropriate description for this parameter.

Almost all eucalypt forests in State forest are subject to wildfire. While dry eucalypt forests can, on occasion, be maintained in the absence of fire [43], wet eucalypt forests require fire to be maintained on the landscape [44]. In dry eucalypt forests, wildfires commonly occur in patches with a relatively short fire-return interval of 4-20 years [45]. In wet eucalypt forests, fire-return intervals vary between 20-100 years in wet sclerophyll forests and 100-350 years in mixed eucalypt/rainforest $([23,24,45]$. Most individual eucalypts in the wetter forests do not survive much beyond 
400 years [46, 47], although maximum longevity has recently been extended to 500 years [48]. Thus, most of the eucalypt component of State forest is likely to have burned at least once in the last 400 years, with most areas likely to have been subject to multiple wildfire events in this period [49]. The area of State forest currently regenerating or regenerated after wildfire includes mature and regrowth eucalypt forest and totals $0.75 \mathrm{Mha}$, representing $79 \%$ of the eucalypt component of State forest and $50 \%$ of total State forest. However, harvested eucalypt forests would have also regenerated following fire, and including silvicultural regeneration categories increases the area of State forest likely to have burned in the last 400 years to $0.94 \mathrm{M}$ ha, namely, the whole eucalypt component. This is equivalent to $63 \%$ of total State forest and $69 \%$ of the native forest component of State forest.

Forestry Tasmania puts considerable effort into fighting fires, spending an average of 2.3 million Australian dollars per year from fire season 2003/2004 to 2008/2009 (Forestry Tasmania unpublished data). This effort has reduced the impact of the 90 average annual unplanned wildfires to an average of $\sim 10000$ ha burnt per year over this time. Across Tasmania between $1945 / 46$ and $1999 / 2000$, wildfires over 24 individual summers burned $>20000$ ha, wildfires over 8 individual summers burned $>60000 \mathrm{ha}$, and in occasional severe fire years much larger areas are burned: for example, in 1972/73, 1966/67, and 1960/61 140 $000 \mathrm{ha}, \sim 170000 \mathrm{ha}$, and $\sim 175000$ ha were burned across Tasmania, respectively $[50,51]$, and earlier historical fires burnt even greater areas.

The area affected annually by all forms of harvesting (clearcut and partial cut) in Tasmania between 2000 and 2010 averaged 33000 ha (range 20000-42000 ha annually [52] of which an annual average of 15000 ha (with a range of 11 000-19000 ha)) was located in State forest [14]. Thus, natural disturbances affect a comparable or larger area of the Tasmanian landscape than harvesting, common to forested systems elsewhere (e.g., [53]). Furthermore, in Victoria during the 2000s, wildfires burned an area equivalent to $\sim 14 \%$ of the State, with fires in two fire seasons burning a total of $2.5 \mathrm{M}$ ha [54]. Natural wildfire has thus left, and will continue to produce, a range of forest age-classes across the Tasmanian landscape and in landscapes around the world [55], as will other natural disturbances such as insect outbreaks [56].

Natural disturbances will prevent State forests from accumulating the maximum amount of tree- $\mathrm{C}$ physiologically possible at the site level across all sites, thus landscapes will not accumulate $\mathrm{C}$ to this theoretical maximum. Many from around the world are concerned wildfires will release large amounts of forest-stored $\mathrm{C}$ to the atmosphere [53, 57-59]. There is also evidence that complete fire suppression can result in fuel accumulation on the landscape, resulting in an increased fire danger $[60,61]$, and in many eucalypt forests of south-eastern Australia, fire is needed to maximise landscape C-stocks. It is thus not possible to achieve landscape Theoretical C Saturation by suppressing fire or other disturbances, and natural disturbances will inevitably return substantial amounts of $\mathrm{C}$ stored in eucalypt forests to the atmosphere, both in Tasmania and around the world.
Thus, the Nabuurs et al. [11] concept of Theoretical C Saturation is correctly named to reflect the improbability of actually achieving $\mathrm{C}$ saturation in landscapes subject to natural disturbances such as fire, as is the case for eucalypt forests across southern Australia.

The eucalypt component of State forest was estimated to be at $69 \%$ Theoretical C Saturation, compared to an (impossible) scenario, where all eucalypt forests were simultaneously to be mature and with high crown cover. However, estimated Theoretical C Saturation for State forest is likely to be overestimated since many forested areas would not be able to attain high crown cover, due to factors such as poor soil fertility and low water availability. Thus, State forest is in fact likely to be several percentage points closer to Theoretical C Saturation. If the eucalypt component of State forest could all be managed to be simultaneously mature at higher crown cover, an additional $65 \mathrm{Tg} \mathrm{C}$ would be stored in State forest (raising its C content from $137 \mathrm{Tg}$ to $202 \mathrm{Tg} \mathrm{C}$ ). This is impossible due to the effects both of wildfire and of succession of wet eucalypt forest to rainforest, which is why the concept of C Saturation is, as Nabuurs et al. [11] describe, theoretical. In any case, saturation would take in excess of 120 years to attain for most forest types and several centuries for the taller, C-rich eucalypt forests $[7,46,47]$.

Not only can tall wet eucalypt forests burn and regenerate as regrowth forests $[19,20]$, but in the absence of fire they can also succeed first to mixed forests then to rainforests. These rainforests are comprised of much smaller trees [23, $24,62]$, and, while accurate rainforest $\mathrm{C}$ densities require experimental confirmation, rainforest $\mathrm{C}$ density is expected to be much lower. This situation, where the pioneer species (Eucalyptus) is long lived and attains large dimensions with no shade tolerant later successional species attaining large dimensions, is ecologically atypical. Temperate forests typically develop with a mixture of shade-intolerant pioneer and shade-tolerant climax tree species $[63,64]$, and succession is not associated with a dramatic reduction in tree dimensions. The atypical ecology of eucalypt forests will impact forest $\mathrm{C}$ stocks and cycles. Thus, understanding regional forest ecology is necessary to properly understand and manage landscape $\mathrm{C}$ dynamics.

The area of wet eucalypt forest that could succeed to rainforest if left undisturbed is large $(0.56 \mathrm{M} \mathrm{ha})$, and would result in a slow but significant and eventually large loss of $\mathrm{C}$ from the landscape. Though it can occur elsewhere in south-eastern Australia, succession of wet eucalypt forest to mixed eucalypt forest to rainforest is largely a Tasmanian phenomenon, because it is restricted to drought-free areas with sufficient rainfall to support rainforest development [65]. Succession of all the current wet eucalypt forest to rainforest would result in a gradual loss of $50 \mathrm{Tg} \mathrm{C}$ from State forest, reducing State forest C stocks to $114 \mathrm{Tg}$. This can be prevented by allowing disturbances such as wildfire, or by forest harvesting with fire-based silviculture $[66,67]$ designed to maintain wet eucalypt forests on the landscape.

Conversely, rainforest can be converted to wet eucalypt forest following repeated or high-intensity fire or some 
forms of silviculture $[19,66,67]$. Wet eucalypt forests are expected to have much larger $C$ densities than rainforests at maturity. Thus, while individual rainforest stands may be at Theoretical C Saturation for that forest type, they were estimated to be at just $34-41 \%$ Theoretical C Saturation of eucalypt forest stands considered capable of replacing rainforest. Thus, for State forest to be reach Theoretical C Saturation, or maximum C stocks, all rainforests would require conversion to mature eucalypt forest. This would add $27 \mathrm{Tg} \mathrm{C}$ to State forest, increasing maximum $\mathrm{C}$ stock from 202 to $229 \mathrm{Tg}$ C. Furthermore, this could only be accomplished by simultaneously allowing the eucalypt forest to age to maturity without burning or forest decline, death or regeneration, eliminating disturbances such as wildfire, insect outbreak, and disease, and halting succession of wet eucalypt forests to rainforest. Even if this were possible, such forest conversion and forest ageing would have negative outcomes for a large component of biodiversity dependent on immature forest types and rainforest. Furthermore, forest stored $\mathrm{C}$ may be returned to the atmosphere through positive feedback loops induced by a warming climate (Friedlingstein et al. [68]). Forest management solely for $\mathrm{C}$ storage may produce distorted outcomes for other forest values; thus, proper forest management requires optimizing a range of forest values.

\section{Conclusions}

Tasmanian State forest is diverse, with a wide range of tree $\mathrm{C}$ densities in different eucalypt forest types and different vegetation types. Recent attention has focussed on the tallest wet eucalypt forests of highest crown cover that are the most C-dense (Forest Class 1 ) that represent $0.2 \%$ of State forest by area. Even at maturity, the remainder of the eucalypt estate has $C$ densities only $21-68 \%$ of that of Forest Class 1, and other cover types (Forest Classes 85-88) have C densities 15$21 \%$ of Forest Class 1 . Clearly, C density values for the most C-dense forests in a landscape, Forest Class 1 in Tasmania, cannot be extrapolated across landscapes.

Further, wet eucalypt forests require fire for initiation and are at their most C-dense at maturity. In the absence of fire, they succeed to rainforest with a lower $\mathrm{C}$ density, which is ecologically atypical. Thus management of forest $\mathrm{C}$ requires an understanding of local forest ecology where patterns observed elsewhere may not be locally applicable.

Theoretical C Saturation for the entire State forest could only be realised if all State forest capable of supporting eucalypt forests were forested by eucalypts, with this eucalypt forest being simultaneously mature. This simultaneous ecological maturity would require regenerating, by fire, all the area capable of supporting eucalypts including that currently supporting rainforest, then preventing in perpetuity all subsequent disturbances such as wildfire, while preventing the transition of mature eucalypt forest to rainforest. This is both impossible and would be ecologically deleterious. Alternative management parameters and paradigms for managing $\mathrm{C}$ at the landscape-scale are, therefore, required.

\section{Acknowledgment}

The authors thank Mark Neyland, John Hickey, Robert Musk, Steve Read, and the anonymous referees for comments on earlier drafts of the manuscript.

\section{References}

[1] M. T. Ter-Mikaelian, S. J. Colombo, and J. Chen, "Fact and fantasy about forest carbon," The Forestry Chronicle, vol. 84, no. 2, pp. 166-171, 2008.

[2] ForestEthics, "Robbing the Carbon Bank: Global Warming and Ontario's Boreal Forest," 2007, http://www.forestethics .org/downloads/globalwarming_2.pdf.

[3] M. Carlson, J. Wells, and D. Roberts, The Carbon the World Forgot: Conserving the Capacity of Canada's Boreal Forest Region to Mitigate and Adapt to Climate Change, Boreal Songbird Initiative and Canadian Boreal Initiative, Seattle, Wash, USA, 2009.

[4] C. Dean, S. Roxburgh, and B. Mackey, "Growth modeling of Eucalyptus regnans for carbon accounting at the landscape level," in Modelling Forest Systems, A. Amaro, D. Reed, and P. Soares, Eds., CAB International, 2003.

[5] C. Dean and G. Wardell-Johnson, "Old-growth forests, carbon and climate change: functions and management for tall open-forests in two hotspots of temperate Australia," Plant Biosystems, vol. 144, no. 1, pp. 180-193, 2010.

[6] S. H. Roxburgh, S. W. Wood, B. G. Mackey, G. Woldendorp, and P. Gibbons, "Assessing the carbon sequestration potential of managed forests: a case study from temperate Australia," Journal of Applied Ecology, vol. 43, no. 6, pp. 1149-1159, 2006.

[7] H. Keith, B. G. Mackey, and D. B. Lindenmayer, "Reevaluation of forest biomass carbon stocks and lessons from the world's most carbon-dense forests," Proceedings of the National Academy of Sciences of the United States of America, vol. 106, no. 28, pp. 11635-11640, 2009.

[8] B. G. Mackey, H. Keith, S. L. Berry, and D. B. Lindenmayer, "Green Carbon, the role of natural forests in carbon storagepart 1, a green carbon account of Australia's south eastern Eucalypt forest, and policy implications," ANU Press, Canberra, Australia, 2008.

[9] P. Cosier, T. Flannery, and R. Harding, Optimising Carbon in the Australian Landscape, Wentworth Group of Concerned Scientists, 2009.

[10] H. Keith, B. Mackey, S. Berry, D. Lindenmayer, and P. Gibbons, "Estimating carbon carrying capacity in natural forest ecosystems across heterogeneous landscapes: addressing sources of error," Global Change Biology, vol. 16, no. 11, pp. 2971-2989, 2010.

[11] G. J. Nabuurs, O. Masera, K. Andrasko et al., "Forestry," in Climate Change 2007: Mitigation. Contribution of Working Group III to the 4th Assessment Report of the Intergovernmental Panel on Climate Change, B. Metz, O. R. Davidson, P. R. Bosch, R. Dave, and L. A. Meyer, Eds., Cambridge University Press, Cambridge, UK, 2007.

[12] W. A. Kurz, S. J. Beukema, and M. J. Apps, "Carbon budget implications of the transition from natural to managed disturbance regimes in forested landscapes," Mitigation and Adaptation Strategies for Global Change, vol. 2, pp. 405-421, 1997.

[13] IPCC, "Guidelines for National Greenhouse Gas Inventories," 2006, http://www.ipcc-nggip.iges.or.jp/public/2006gl/pdf/4_ Volume4/V4_04_Ch4_Forest_Land.pdf. 
[14] Forestry Tasmania, "Sustainability Charter: Forest Management Plan,” 2008, Forestry,Hobart, Tasmania.

[15] Commonwealth of Australia, Australia's Forests at a Glance, Bureau of Rural Sciences, Canberra, Australia, 2009.

[16] Forestry Tasmania, "Stewardship Report 2008-2009," 2009, Forestry Tasmania, Hobart, Tasmania.

[17] M. G. Stone, "Forest-type mapping by photo-interpretation: a multi-purpose base for Tasmania's forest management," Tasforests, vol. 10, pp. 15-32, 1998.

[18] J. E. Hickey, "Mapping Tasmania's tall eucalypt forests," in The Tall Eucalypt Workshop, M. J. Brown, S. J. Jarman, and K. J. Williams, Eds., Forestry Commission, Hobart, Tasmania, 1987.

[19] Forestry Tasmania, "Lowland wet eucalypt forests," Native Forest Silviculture Technical Bulletin 8, Forestry Tasmania, Hobart, Tasmania.

[20] Forestry Tasmania, "Lowland wet eucalypt forests," Native Forest Silviculture Technical Bulletin 3, Forestry Tasmania, Hobart, Tasmania.

[21] Public Land Use Commission, "Tasmanian-Commonwealth Regional Forest Agreement background report Part C," Environment and Heritage Report, Tasmanian Public Land Use Commission in conjunction with Commonwealth Forests Taskforce, 2, 1996.

[22] W. D. Jackson, "Vegetation types," in Vegetation of Tasmania, J. B. Reid, R. S. Hill, M. J. Brown, and M. J. Hovenden, Eds., Flora of Australia Supplementary Series, Australian Biological Resources Study, Commonwealth of Australia, University of Tasmania, Forestry Tasmania, CRC for Forestry, Hobart, Tasmania, 1999.

[23] J. M. Gilbert, "Forest succession in the Florentine valley, Tasmania," Papers and Proceedings of the Royal Society of Tasmania, vol. 93, pp. 129-151, 1959.

[24] W. D. Jackson, "Fire, air, water and earth-an elemental ecology of Tasmania," Proceedings of the Ecological Society of Australia, vol. 3, pp. 9-16, 1968.

[25] K. W. Cremer, "Distance of seed dispersal in eucalypts estimated from seed weights," Australian Forest Research, vol. 7, pp. 225-228, 1977.

[26] MBAC, Forestry Tasmania's Carbon Sequestration Position, MBAC Consulting Group Pty Ltd., Melbourne, Australia, 2007.

[27] S. B. Whiteley, "Calculating the sustainable yield of Tasmania's State forests," Tasforests, vol. 11, pp. 23-34, 1999.

[28] S. J. Jarman, M. J. Brown, and G. Kantivilas, Rainforests in Tasmania, National Parks and Wildlife Service, Tasmania, 1984.

[29] J. E. Hickey, S. Davis, R. Wardman, and J. Harris, "How much rainforest is in Tasmania? A better answer to a difficult question," Tasforests, vol. 5, pp. 13-24, 1993.

[30] Commonwealth of Australia and State of Tasmania, "Tasmanian Regional Forest Agreement between the Commonwealth of Australia and the State of Tasmania," 1997, http://www.daff .gov.au/_data/assets/pdf_file/0003/49278/tas_rfa.pdf.

[31] J. Ilic, D. Boland, M. McDonald, G. Downes, and P. Blakemore, "Woody density phase 1-state of knowledge," National Carbon Accounting System Technical Report 18, Australian Greenhouse Office, Canberra, USA, 2000.

[32] P. Snowdon, D. Eamus, and P. Gibbons, "Synthesis of allometrics, review of root biomass and design of future woody biomass sampling strategies," National Carbon Accounting System Technical Report 17, Australian Greenhouse Office, Canberra, Australia, 2000.
[33] Tasmanian Regional Forest Agreement, Agreement between the Commonwealth of Australia and the State of Tasmania, 1997.

[34] Forest Practices Board, "Forest Practices Code," 2000, Forest Practices Board, Hobart, Tasmania.

[35] Forestry Tasmania, "A new silviculture for Tasmania's public forests: a review of the variable retention program," 2009.

[36] Melbourne Water, 2010, http://www.melbournewater.com.au/ content / water _ storages / bushfires_in_catchments/february_ 2009_-_catchment_impact_table.asp?bhcp=1.

[37] J. Norris, S. Arnold, and T. Fairman, "An indicative estimate of carbon stocks on Victoria's publically managed land using the FullCAM carbon accounting model," Australian Forestry, vol. 73, pp. 209-219, 2010.

[38] R. C. Dewar, "A model of carbon storage in forests and forest products," Tree Physiology, vol. 6, no. 4, pp. 417-428, 1990.

[39] R. C. Dewar, "Analytical model of carbon storage in the trees, soils, and wood products of managed forests," Tree Physiology, vol. 8, no. 3, pp. 239-258, 1991.

[40] M. E. Harmon, W. K. Ferrell, and J. F. Franklin, "Effects on carbon storage of conversion of old-growth forests to young forests," Science, vol. 247, no. 4943, pp. 699-702, 1990.

[41] F. Duncan and M. J. Brown, Dry Sclerophyll Vegetation in Tasmania: Extent and Conservation Status of the Communities, Wildlife Division Technical Report no. 85/1, National Parks and Wildlife Service, Tasmania, Australia, 1985.

[42] Australian Government, Tasmanian Community Forest Agreement. Research into Alternatives to Clearfelling in Old Growth Forests. Operating Plan, Department of Agriculture, Fisheries and Forests, Canberra, Australia, 2005.

[43] F. Duncan, "Dry sclerophyll forests and woodlands," in Vegetation of Tasmania. Australian Biological Resources Study, J. B. Reid, R. S. Hill, M. J. Brown, and M. Hovenden, Eds., pp. 244-264, Tasmania, Australia, 1999.

[44] P. Wells and J. Hickey, "Wet sclerophyll, mixed and swamp forests," in Vegetation of Tasmania, J. B. Reid, R. S. Hill, M. J. Brown, and M. Hovenden, Eds., pp. 244-264, Australian Biological Resources Study, Tasmania, 1999.

[45] A. B. Mount, "Natural regeneration processes in Tasmanian forests," Search, vol. 10, pp. 180-186, 1979.

[46] P. J. Alcorn, J. K. Dingle, and J. E. Hickey, "Age and stand structure in a multi-aged wet eucalypt forest at the Warra silvicultural system trial," Tasforests, vol. 13, pp. 245-260, 2001.

[47] M. R. Jacobs, Growth Habits of the Eucalypts, Forestry and Commonwealth Timber Bureau, Canberra, Australia, 1955.

[48] S. W. Wood, Q. Hua, K. J. Allen, and D. M. J. S. Bowman, "Age and growth of a fire prone Tasmanian temperate old-growth forest stand dominated by Eucalyptus regnans, the world's tallest angiosperm," Forest Ecology and Management, vol. 260, no. 4, pp. 438-447, 2010.

[49] P. A. M. Turner, J. Balmer, and J. B. Kirkpatrick, "Standreplacing wildfires? The incidence of multi-cohort and singlecohort Eucalyptus regnans and E. obliqua forests in southern Tasmania," Forest Ecology and Management, vol. 258, no. 4, pp. 366-375, 2009.

[50] Australian Government and Tasmanian Government, Sustainability indicators for Tasmanian forests 2001-2006, 2007, Prepared by the Tasmanian and Australian governments for the 2007 Ten Year Review of the Tasmanian Regional Forest Agreement.

[51] B. Walker and K. Felton, "Section 4; Tasmania," in Forest Management in Australia: Implications for Carbon Budgets. National Carbon Accounting System Technical Report No. 32, R. J. Raison and R. O. Squire, Eds., pp. 147-192, Australian Greenhouse Office, Canberra, Australia, 2007. 
[52] Forest Practices Authority, 2010, http://www.fpa.tas.gov.au/ index.php?id=81\&tx_avotherresources_pi1[action] =ResByCat \&tx_avotherresources_pil[cat] $=2$.

[53] W. A. Kurz, G. Stinson, G. J. Rampley, C. C. Dymond, and E. T. Neilson, "Risk of natural disturbances makes future contribution of Canada's forests to the global carbon cycle highly uncertain," Proceedings of the National Academy of Sciences of the United States of America, vol. 105, no. 5, pp. 1551-1555, 2008.

[54] Government of Victoria, 2010, http://www.dse.vic.gov.au/ DSE/nrenfoe.nsf/childdocs/-D79E4FB0C437E1B6CA256DA 60008B9EF?open.

[55] D. M. J. S. Bowman, J. K. Balch, P. Artaxo et al., "Fire in the earth system," Science, vol. 324, no. 5926, pp. 481-484, 2009.

[56] W. A. Kurz, C. C. Dymond, G. Stinson et al., "Mountain pine beetle and forest carbon feedback to climate change," Nature, vol. 452, no. 7190, pp. 987-990, 2008.

[57] D. Schimel and D. Baker, "Carbon cycle: the wildfire factor," Nature, vol. 420, no. 6911, pp. 29-30, 2002.

[58] G. R. Van Der Werf, J. T. Randerson, L. Giglio, G. J. Collatz, P. S. Kasibhatla, and A. F. Arellano, "Interannual variability of global biomass burning emissions from 1997 to 2004," Atmospheric Chemistry and Physics Discussions, vol. 6, no. 2, pp. 3175-3226, 2006.

[59] D. M. Kashian, W. H. Romme, D. B. Tinker, M. G. Turner, and M. G. Ryan, "Carbon storage on landscapes with standreplacing fires," BioScience, vol. 56, no. 7, pp. 598-606, 2006.

[60] W. A. Kurz and M. J. Apps, "A 70-year retrospective analysis of carbon fluxes in the Canadian Forest Sector," Ecological Applications, vol. 9, no. 2, pp. 526-547, 1999.

[61] C. Wiedinmyer and M. D. Hurteau, "Prescribed fire as a means of reducing forest carbon emissions in the western United States," Environmental Science and Technology, vol. 44, no. 6, pp. 1926-1932, 2010.

[62] R. C. Ellis, "The relationships among eucalypt forest, grassland and rainforest in a highland area in north-eastern Tasmania," Australian Journal of Ecology, vol. 10, no. 3, pp. 297-314, 1985.

[63] F. H. Bormann and G. E. Likens, Pattern and Process in a Forested Ecosystem, Springer, New York, NY, USA, 1979.

[64] C. J. Burrows, Processes of Vegetation Change, Unwin Hyman, London, UK, 1990.

[65] J. R. Busby, "A biogeoclimatic analysis of Nothofagus cunninghamii (Hook.) Oerst. In southeastern Australia," Australian Journal of Ecology, vol. 11, no. 1, pp. 1-7, 1986.

[66] T. M. Cunningham and K. W. Cremer, "Control of the understory in wet eucalypt forests," Australian Forestry, vol. 29, pp. 4-14, 1965.

[67] J. E. Hickey, "A floristic comparison of vascular species in Tasmanian oldgrowth mixed forest with regeneration resulting from logging and wildfire," Australian Journal of Botany, vol. 42, no. 4, pp. 383-404, 1994.

[68] P. Friedlingstein, P. Cox, R. Betts et al., "Climate-carbon cycle feedback analysis: results from the C4MIP model intercomparison," Journal of Climate, vol. 19, no. 14, pp. 3337-3353, 2006. 

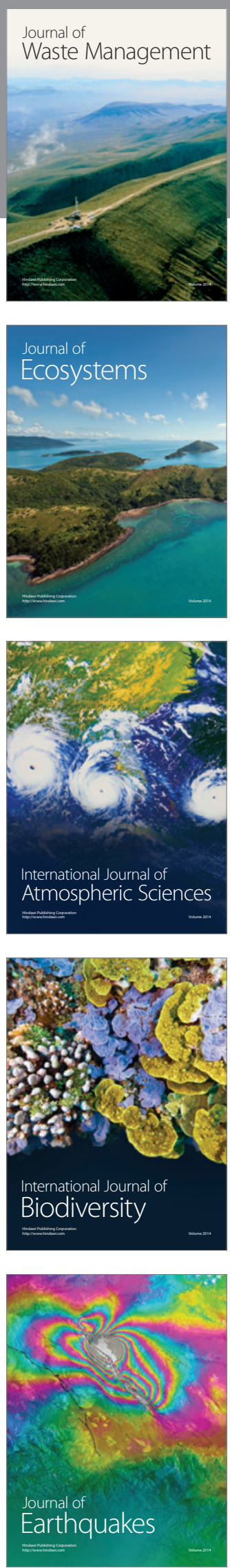
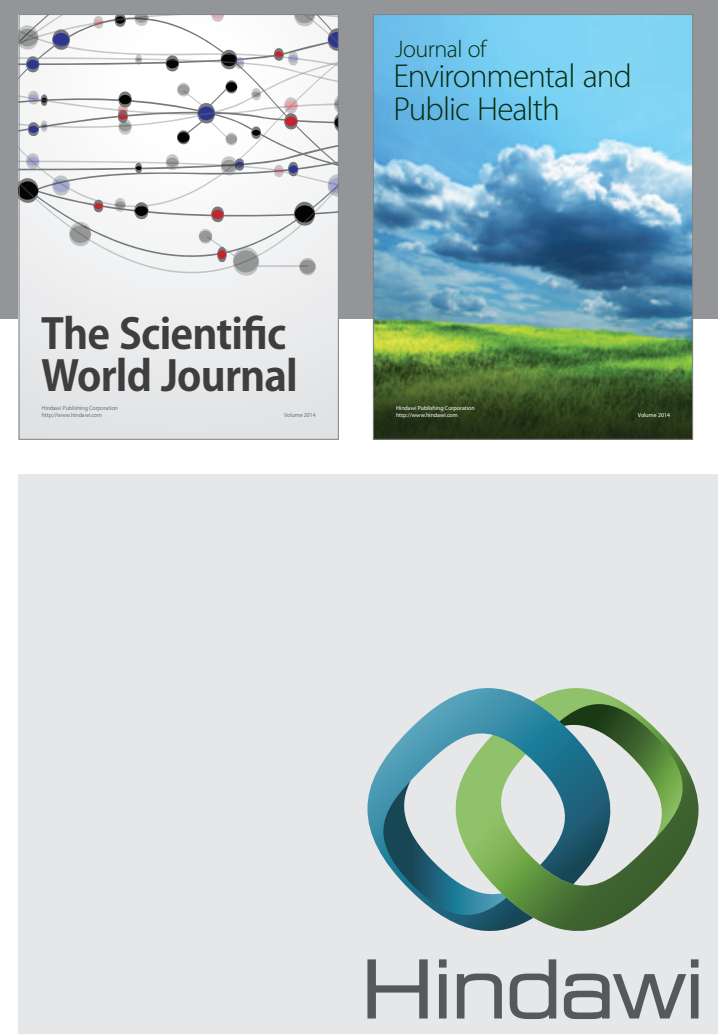

Submit your manuscripts at

http://www.hindawi.com
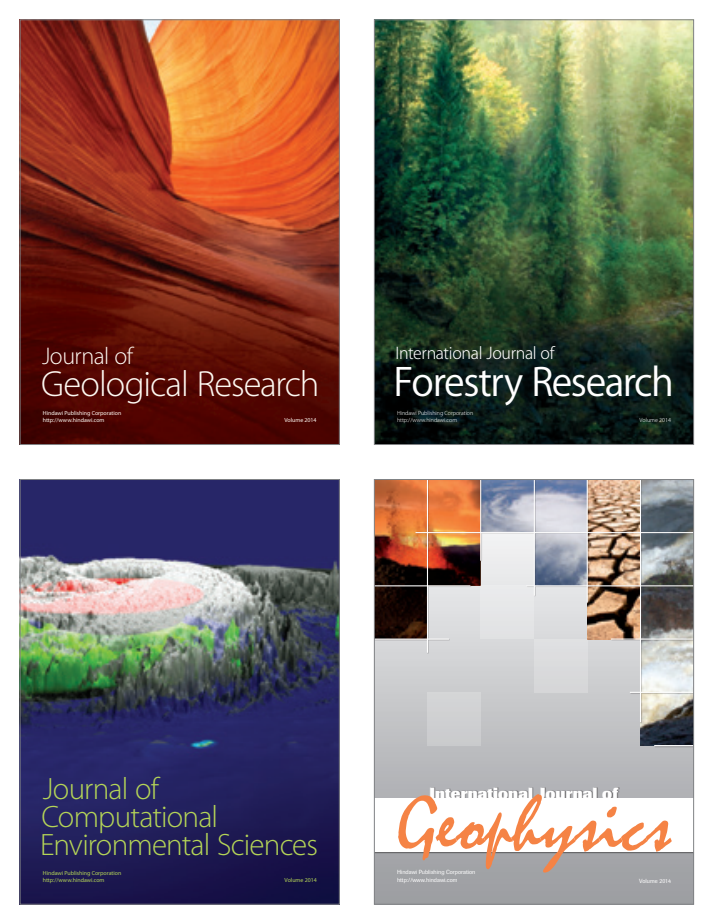
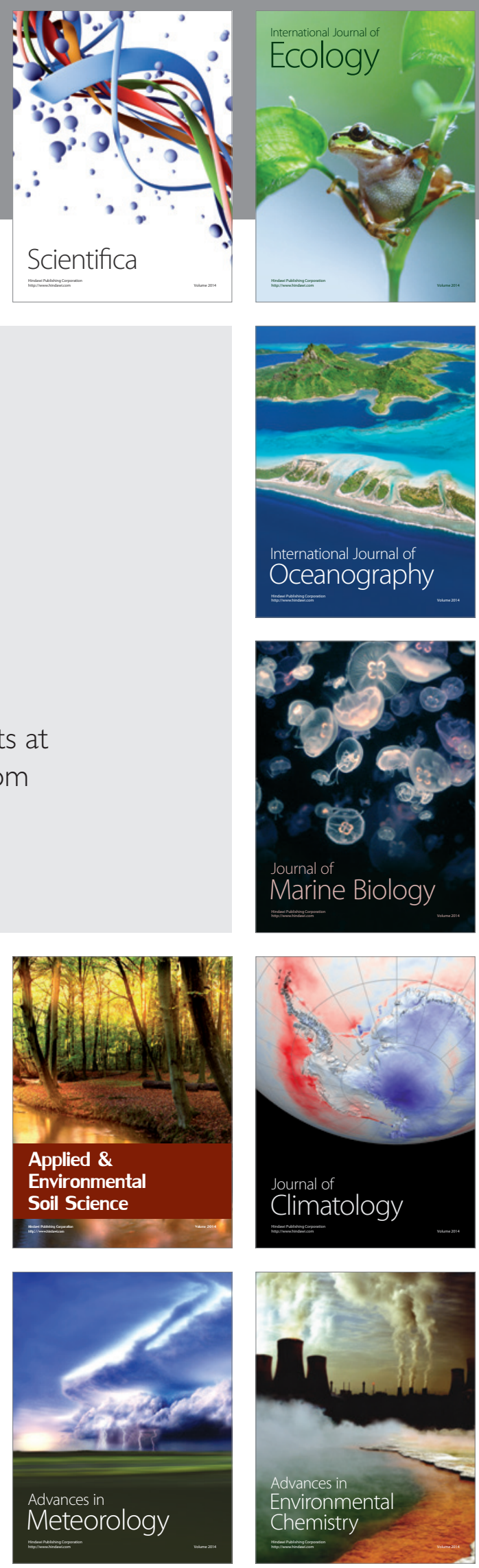